(1) 1982 ISIJ

\title{
連続鋳造における粒状等軸晶の生成と沈降堆積 論
}

\section{Formation and Sedimentation of Globulites in Continuous Casting}

\author{
Klaus Wünnenberg* and Hatto JAGOBI*2
}

\begin{abstract}
Synopsis:
The extension of columnar or equiaxed zone in the as-cast structure of continuously cast slabs is primarily affected by the superheat temperature in the tundish, high temperatures promoting the formation of columnar grains and low temperatures that of equiaxed grains. At an intermediate temperature a sharp transition in the extent of each structure occurs. The formation of equiaxed crystals is enhanced by high freezing rates of the solid shell and by turbulent fluid flow. Under favourable conditions free crystals already exist in the mould. In bow type machines sedimentation of such suspended crystals is a geometrical phenomenon and depends on parameters such as machine radius, casting speed and heat extraction.

The experiment shows that in slabs of bow type machines the cast structure is asymmetric, the equiaxed zone extending further to the outer radius. At intermadiate superheat temperatures sedimentation zone is entirely located within the lower strand section terminating distinctly below the centre line. Consequently the formation of free crystals may end before completion of strand solidification. Concentration profiles of partly equiaxed solidified slabs are used to verify the sedimentation mechanism. Carbon is taken as an example to illustrate the decrease of concentration in equiaxed zone.
\end{abstract}

1. 緒言

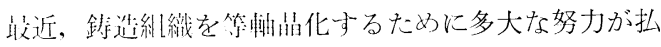

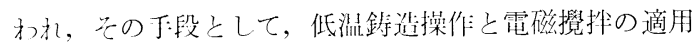

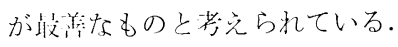

\section{2. 浮遊結晶の生成}

低沙鋳暹の際には，浮遊絓唱が抯に鋳型部において生 成し始めるが，この浮遊絬: 品は凝湖款が此較的薄い領域 で㠜湖界而の絬昆が浴鋼流動によつて增殖されるために 生成すると考えられる 鋼よりも漟度が大きいため沈降する倾向に西り, 沈降中, 特に溶鋼が刘流している場合には命体して大きなクラス ターになり，分岐状デンドライトが再溶解して最終的に 精状等軸晶（本淪文では，以下単飞䊉状品之呼ぶ。）に

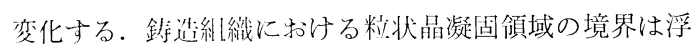

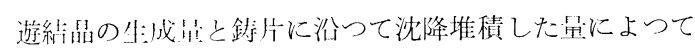
沈まる。

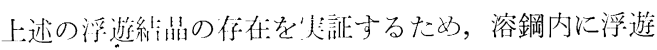
する鉄の結涪で浮遊初期の状態におけるるのをPhoto. 1 に示す。なお，Photo. 1 の組織写真は鋳片表面に平行

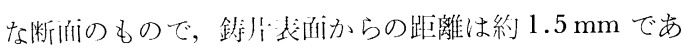
る. Photo. 1 (a) 飞兄られる浮遊結晶は低合金炭素鋼
に执いて典型的なもので，過冷溶鋼の流動によつて鋳型 以湯面近傍の凝固殼に捕捉されたと考兄られる。この場 合，溶鋼中に扎ける浮遊結晶の洲留時間が短いためにデ ンドライト状の成長がそのま保存され，デンドライト やその破片が乱流によつてクラスター状になつている。 Photo. 1(b) は高合金フェライトおよびオーステナイ 卜鋼に観察される典型的な浮遊結晶を示す。浮遊結晶は 再溶解して粒状晶のクラスターになつている. Photo. 1 の上と下の組織写真を比較すると, 下の写真に抢ける浮 遊結晶の数は上のものより多いが, 粒径はむしろ小さい ことがわかる.

組織写真の調査から得られた結論は次のと扮りであ る. 白由に浮遊している鉄絬晶の形態は, 鋼種, 冷却速 度並びに溶鋼プールの撜拌方法や強さに依存する。 た，溶鋼中に抢ける懸濁粒子の形状・個数・大きさなど は鋼種にもよるが空間的に不均質で時間的にも変動する と考えられるため, 結晶の沈降速度や結晶周囲の流れに 基づいて実際の沈降堆積機構を理論的に洞察することは 難しい。これに対して, 連続鋳造に打ける結晶沈降堆積 現象を幾何学的に検討することは重要であり, 理論的に もずつと取り扱いやすいので, 以下にその基礎的検討を 行う.

将利 55 年: 11 月第 4 同日独七ミナーにて発表

* Mannesmann Research Institute, Dr.-Ing.

*2 Mannesmann Research Institute, Dr. rer. nat (Mannesmann Forschungsinstitut GmbH, Ehinger Str. 200, D-4100 Duisburg 25, West-Germany.) 草：富沢萝… (名古屋大学工学部 工博) 

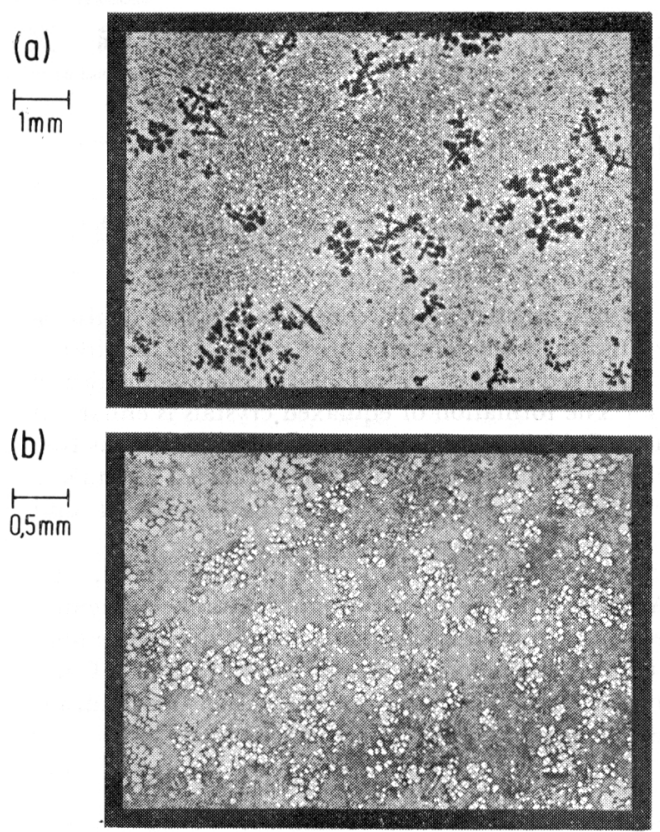

Photo. 1. Suspension of dendritic and globular crystals in steel melt, (a) low-alloy carbon steel, (b) high-alloy ferritic steel.

\section{3. 沈降堆積に関する理論解析}

スラブ鋳片を低温鋳造する場合，溶鋼内で結晶の不均 質核生成がないものと仮定すれば，結晶の沈降堆積に関 して以下に示す両極端の場合が考党られる.

（1）垂直型連鋳の場合：相対した 2 つ㠜固前面で 浮遊結晶が生成されるため粒状晶の生成量は比較的多 く, 結晶は溶鋼プールの底部李で沈降し, その最大沈降 距離はプール深さに等しい。粒状晶帯は鋳片中心線に関 して対称になる。

（2）水平型連鋳の場合：上面側凝固前面でのみ浮遊 結晶が生成されるため粒状晶の生成量は比較的少なく, 結晶は下面側凝固前面まで沈降し，父の最大沈降距離は 溶鋼プールの厚さに等しい。粒状晶带は鋳片中心線に関 して非対称であり鋳片下面側に偏倚している。

湾曲型連鋳機に括いて，鋳片は垂直部から湾曲部を経 て水平方向に引き抜かれるが，この間に，上述したよう な特徵が現れることになる。治金的条件が同一の場合， 堆積によつて生じる粒状晶帯の位置や厚さは, 最終的に 連鋳機の半径，鋳片引き抜き速度特よび鋳片表面からの 抜熱速度に依存すると考兄られ。

結晶の沈降堆積機構を把握して鋳造組織をある程度予 測するためには，湾曲型連鋳機の鋳片傾斜部に抢ける上 下面側凝固前面間の垂直距離を知つて扣く必要がある.

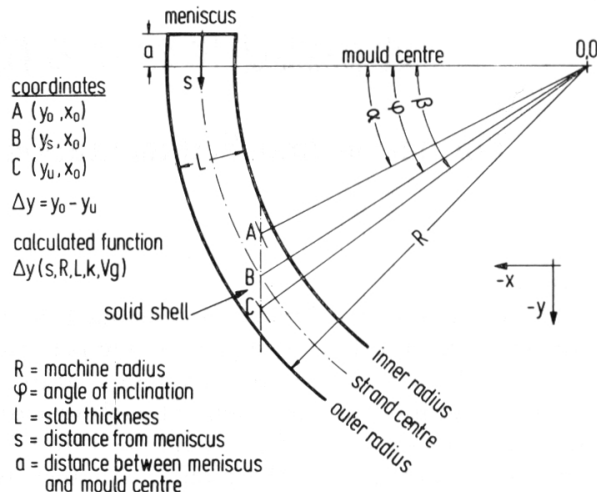

Fig. 1. Geometric model of a bow-type continuous caster.

この距離は Fig. 1 に示すよらな連鋳機の幾何形状に基 ついて算出することができる。ここで，Fig. 1 に执け る 3 つの角, $\alpha, \beta, \varphi$ は鋳型の水平中心面となす角とし て定義する。亦た, 点 $\mathrm{A}\left(y_{\mathrm{o}}, x_{\mathrm{o}}\right)$ 拈よび $\mathrm{C}\left(y_{\mathrm{u}}, x_{\mathrm{o}}\right)$ は $x=-x_{0}$ の垂線が括の扮の上面側扣よび下面側凝固前面 と交わる点であり，点 $\mathrm{B}\left(y_{\mathrm{s}}, x_{\mathrm{o}}\right)$ は垂線と鋳片中心線と の交点を示す.

溶鋼に過熱がなく，凝固殼の成長が凝固の放物線則 $(d=k \sqrt{t}, d$ : 凝固殼厚さ, $k$ : 凝固定数, $t$ : 時間 $)$ に 従うと仮定すると，上下面側の凝固前面の位置に関して

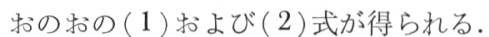

$$
\begin{aligned}
& -y_{\mathrm{o}}=\left[R-L+\frac{k}{\sqrt{V_{\mathrm{g}}}} \cdot\left\{a+\left(R-\frac{L}{2}\right) \cdot \frac{\pi \alpha}{180}\right\}^{\mathbf{1} / \mathbf{2}}\right] \\
& \times \sin \left(\frac{\pi \alpha}{180}\right) \\
& -y_{\mathrm{u}}=\left[R-\frac{k}{V V_{\mathrm{g}}} \cdot\left\{a+\left(R-\frac{L}{2}\right) \cdot \frac{\pi \beta}{180}\right\}^{1 / 2}\right] \\
& \times \sin \left(\frac{\pi \beta}{180}\right)
\end{aligned}
$$

ここで, $R$ : 連鋳機の半径, $V_{\mathrm{g}}$ : 鋳片引き拔き速度, $a:$ 湯面から鋳型の水平中心面までの距離, $L$ : スラブ厚さ.

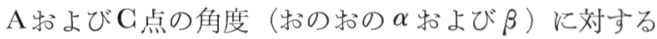
条件式として (3) 式が与えられる.

$$
\begin{aligned}
& -x_{\mathrm{o}}=\left[R-L+\frac{k}{\sqrt{V_{\mathrm{g}}}} \cdot\left\{a+\left(R-\frac{L}{2}\right) \cdot \frac{\pi \alpha}{180}\right\}^{\mathbf{1} / \mathbf{2}}\right] \\
& \times \cos \left(\frac{\pi \alpha}{180}\right) \\
& =\left[R-\frac{k}{\sqrt{V_{\mathrm{g}}}} \cdot\left\{a+\left(R-\frac{L}{2}\right) \cdot \frac{\pi \beta}{180}\right\}^{\mathbf{1 / 2}}\right] \\
& \times \cos \left(\frac{\pi \beta}{180}\right)
\end{aligned}
$$

$\mathrm{B}$ 点に関与る鋳片傾斜角 $(\varphi)$ と $x$ 座標との関係は (4) 式で表現される. 


$$
\varphi=\left\{\operatorname{Arccos}\left(\begin{array}{c}
-x_{0} \\
R-L / 2
\end{array}\right)\right\} \cdot \begin{gathered}
180 \\
\pi
\end{gathered}
$$

鋳片中心線に测つた晹而からの距離（ $s$ ）は独立変数 であり，鋳片倾斜侧との间に次の(5)式の関係がある。

$$
s=a+(R-L / 2) \cdot(\pi \varphi / 180)
$$

なお，凝湖の放物線則， $t=s / V_{\mathrm{g}}$ の関係および $(5)$ 式

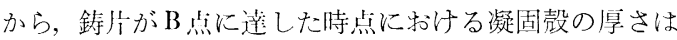
鋳片傾斜的の関数として $(6)$ 式で与えられる.

$$
d(\varphi)=\left(k / V V_{\mathrm{g}}\right) \cdot[a+(R-L / 2) \cdot(\pi \varphi / 180)]^{1 / 2}
$$

上述の $(1) \sim(5)$ 式を用いて，上而側凝团前面から沈 降結唱が堆積し始める下泊側凝固前面までの 垂但距離 $\left(J y=y_{\mathrm{o}}-y_{\mathrm{u}}\right)$ を距離 $s$ ないは鋳片傾斜角の関数とし て求めることができる、鋳片傾斜所は沈降結晶の堆積開 始位盖を汱める重要な変数であり，鋳型の重直部伯下か ら鋳覑曲泮栙が定である領域に限れば，(5)式を 変形した $(7)$ 式を使つて算出できる.

$$
\varphi=(180 / \pi) \cdot(s-a) /(R-L / 2)
$$

趣祭の連鋳機に扮ける鋳片傾斜的 $(\varphi)$ と鋳片中心線 に沿つた晹面からの距離（ $s$ ）との関係を Fig. 2 に示 す。ここでは, 初期半径が小さな 2 種類の多点曲げ型連 鋳機 $(R=3.9$ および $5.0 \mathrm{~m})$ ，および，比較のために， 最近の円孤型进錯機 $(R=10.5 \mathrm{~m})$ の場合を例にとつて

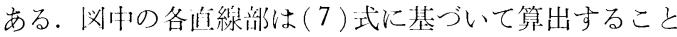
ができ，晹俑から鋳型の水平中心面までの距離として $a=0.3 \mathrm{~m}$ を採用した。 また，初期半径が $R=3.9 \mathrm{~m}$ の

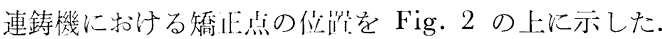
同図から，连鋂機の半径が小さい場合，鉛直線に対する 鋳片傾斜们が晹泊からの距離の増加に伴つて急速に大き くなることがわかる。そのため，このような場合には， 卜面側凝国㓩们への沈降約晶の堆積が早い時点すなわち 湯面から比較的知い距離で起こり，それと同時にト面側 凝固角面はもはや浮遊紹昆の生成場所にはなり得ないと 考えられる。

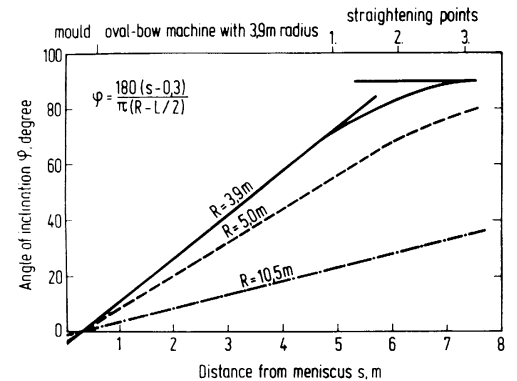

Fig. 2. Angle of strand inclination relative to the vertical in bow-type casters of varying radii.

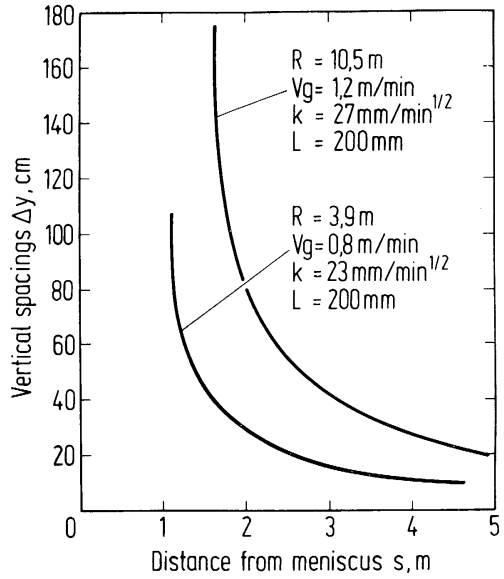

Fig. 3. Vertical spacings between solidification fronts on bow-type casters at varying plant radii, castir speeds and cooling rates.

上述した結果は幾何学的考察のみから得られたもので あり，さらに検討する必要がある。半径がおのおの 3.9 および $10.5 \mathrm{~m}$ である湾曲型連鋳機に関し，上下面側凝 固前面間の垂淔距離の 推算結果を Fig. 3 と示す。 な お，計算条件は図中に示したと拈りで奉操業での值を採 用したが，本計算では連鋳機の半径 $(R)$ は沶のおの一 定とした，一般に，大きな半径を有する最近の円弧型連 鋳機は高速鋳造用に設計されて扣り，溶鋼プールが深く なる傾向にあるが，Fig. 3 の結果からわかるように， 連鋳機の半径による凝固液面間垂直距離の本質的な差異 は湯面から短区間においてのみ現れ，その後湯面からの 距離の増加に伴つて垂直距離は互いに漸近する。それ 故, 湯面から最初の数 $\mathrm{m}$ の区間に扮ける結晶の沈降堆積 機構が，鋳片内に堆積した粒状晶帯の位置や厚さを沈め るものと考㝋られ。

\section{4. 粒状晶堆積層の位置と厚さ}

ここでは，前章で述べた理論解析の結果を確かめる日 的で，半径が扮の拈の 3.9 抢よび $10.5 \mathrm{~m}$ の湾曲型スラ ブ連鋳機を使つた実験の結果に基づき，堆積して生じた 粒状晶带の鋳片内における位置や厚さ，およびその組織 形態を検討する.

沈降結晶の量が鋳造中の溶鋼過熱度に依存することは 一般に知られており ${ }^{2)}$ ，タンディシュと鋳型内における 溶鋼の連続測温から，溶鋼が鋳型内に存在する間に過熱 が急速に除去されることがわかる．本研究では多数の連 続測温を行つたが，その結果をFig. 4 に示す.鋳型内 溶鋼温度は注入流衝突位置下部の狭面側鋳型壁付近で測 定した．Fig. 4 において，タンディシュ内の溶鋼過熱 


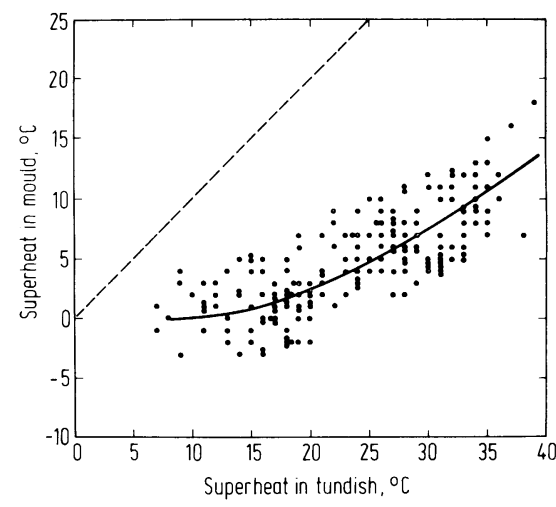

Fig. 4. Superheat reduction of melt between tundish and mould, measured near narrow face.

度が比較的小さい場合，鋳型内温度はタンディシュ内の 溶鋼過熱度にほぼ無関係にごく短時間で液相線温度近く まで常に低下するように見える。このことは，タンディ シュ内溶鋼過熱度の変化に伴つて凝固組織が系統的に変 化するという後述の実験結果と相反するものである。な お，後述するよらに，タンディシュ内溶鋼過熱度は凝固 組織との関連において最も重要な操業变数である2) 99).

半径 $R=5.0 \mathrm{~m}$ の湾曲型連鋳機で鋳造したスラブ鋳片 の凝固組織を系統的に調查した。使用した鋼種は Al-キ ルド鋼 $(0.10 \% \mathrm{C}, 1.50 \% \mathrm{Mn})$ で，鋳造速度は $V_{\mathrm{g}}=1.0$ $\mathrm{m} / \mathrm{min}$ である.タンディシュ内に冷却用の小径スクラ ップを規定量投入することにより，低滥鋳造条件を再現 性よく設定した。本実験で得られたスラブ厚さに対す る粒状等軸晶帯厚さの割合いを Fig. 5 に示す。同図か ら，過熱度の低下に伴い鋳造温度がある值（本論文で は，これを遷移温度と呼ぶ.）より低くなつて初めて粒 状晶の形成が急に始まることがわかる(3) 度は液相線温度より $13^{\circ} \mathrm{C}$ ほど高い。堆積して生じた粒

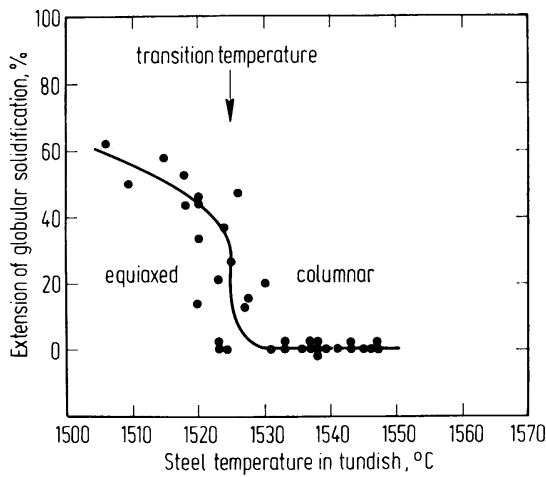

Fig. 5. Solidification structure as a function of casting temperature.

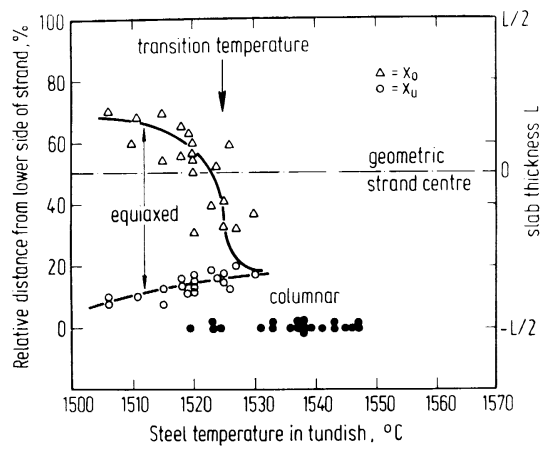

Fig. 6. Location and expansion of globular solidification zone as a function of casting temperature. $x_{0}=$ upper and $x_{u}=$ lower limitation of globular piling)

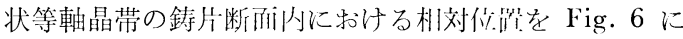
示す。すなわち，同比はタンディシュ内浴鋼温庭の変動 に伴う粒状等軸晶带の上而側および下而側境哭位消の変

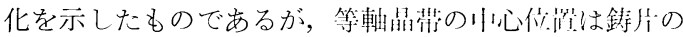
幾何学的中心線に一致せず，尖質似に久ラブのド面側一 移動している7)10) 13).

上述の実験において，タンディシュ队浴鋼温是を低減 するために溶鋼とほぼ间紬成のハクラップの拕人を行つ たが，スクラップ片の形状は怗さ 10〜 $50 \mathrm{~mm}$ ，㜚 20〜 $50 \mathrm{~mm}$ 抢よび长さ $100 \sim 200 \mathrm{~mm}$ で，未溶解のまま夕 ンディシュの底に堆积増加しないよらに技人りを規制し て定常的な溶解に留㥁した。得られた凃け内にンクラッ

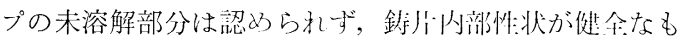
のであつたことから，スクラップはタンディジュ内です ベて溶解したと推察される。したがつて，本飐駼条件下 でのスクラップ投入は単にタンディシュ浴鋼温度を低 減する効果しかないと考光られるが，タンディシニ内溶 鋼温度が液相線温度に極好て近い坋介、 未溶解久クラッ プが溶鋼以の浮遊結晶の算に度ぼす效果については今後 の定量的検討が必装と思われる.

粒状晶の堆積層が鋳造組織の中に突然現れたり消えた りする狭い堂移温度領域が存在するが，これは絬品の沈 降堆積現象を理解する際に重装である。收小半径 $(R=$ $3.9 \mathrm{~m})$ の連鋳機で鋳造した久ラグ鋯片のト面側断面に 扣ける凝固組織をPhoto. 2 に示す。この組織写真から 遷移温度領域に招ける組織形成の㥆于が明らかになる。 すなわち，この写具の上部に沶いて組い折れ總状のもの が左右に通つているが，こ扎は上ト南側から進行してき た凝固の完了位䈯を示し，鉿帅小心線にほぼー致する。 下面側から上面側へ進行与る結晶堆棈領域の抁大は中心 線に到達する前で明らかに止まつて特り，その後中心線 


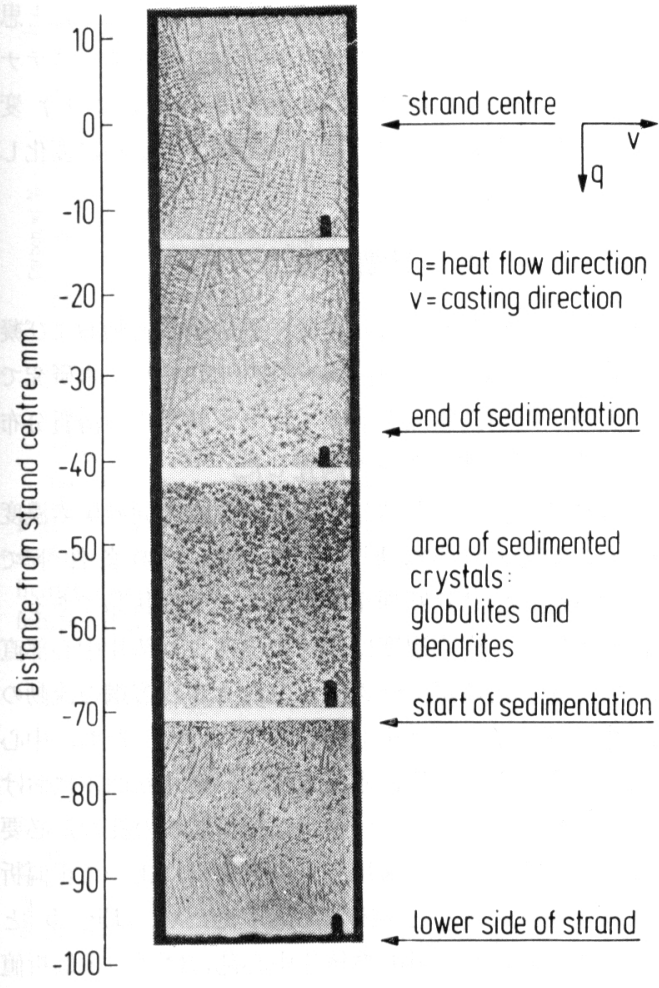

Photo. 2. Solidification structure in lower half of a strand slab when casting at "transition temperature".

まで柱状晶凝固が生じている。したがつて, 浮遊結晶の 生成と沈降堆積は，時間的にも場所的にも鋳片の凝固が 完了寸る以前に終了する。Fig. 6 からわかるように， 遷移領域に掞いては，鋳造温度のわずかな上昇によつて 粒状晶の量が減少し，これに伴い堆積層の上面側境界は 下面側へ移動する。一方，下面側境界は変化せずほぼ定 位置に留まる。結晶沈降は鋳造温度が高い汪ど早い時期 に終わるようである。

沈降結晶が下面側凝固前面に堆積し始める位置やそこ での凝固殼の厚さは，主として，幾何学的因子である鋳 片傾斜角によつて決まる。このことは，実操業に即した 鋳造速度と冷却速度の条件下で, 種々の湾曲型連鋳機を 使つたスラブ鋳片の鋳造実験によつて確かめられた。下 面側鋳片表面から堆積層下面側境界までの距離は連鋳機 の半径に依存して拈り， $R=3.9 ， 5.0$ 拈よび $10.5 \mathrm{~m}$ の 各半径に対して，おの抒の，26，32，45 mm で，これ に対応する鋳片傾斜角は各半径の場合とも沶拈よと 16 でありた。

\section{5. 粒状晶堆積層の組織構造}

スラブ鋳片下面側に拈ける粒状晶堆積層の組織形態の 調查から，婎積した粒状晶の平均粒子分率（ここで，粒 子分率とは鋳片単位体積中の粒状晶の体積割合を意味す る.）が堆積層厚さの増加に伴つて大きくなること, 掞よ び，粒状晶の局所的な粒子分率は堆積層内に拈いて下面 側から上面側へ行くに従つて増加することがわからた。

Photo. 2 に示されるよらな平担で薄い堆積層に执いて は, 䊉状晶は常に粗に充填されている.遷移温度付近の条 件下では，堆積層の下面側境界で数個の等軸デンドライ トが柱状晶組織内に分散した状態になつており，そこか ら沈降結晶の堆積が始まつているよらに見党る。一方, 堆積層の上面側境界が鋳片中心線に近ついたり，中心線 を越える活ど堆積層が厚い場合には，粒状晶は常に密に 充填されている.

堆積層内に打ける組織形態の位置的変化を確かめるた め，熱流の向きに平行ないしは垂直な断面の組織写真を 使い, Photo. 2 のスラブ鋳片の凝固組織を調査した. 鋳片断面内各位置に括けるデンドライトの 1 次抒よび 2 次アーム間隔の実測值を Fig. 7 に示寸.この図に扣け る傾向は他の研究者3) 10) 11) 14) 17) の実測結果とよく一致 する. 結晶堆積現象は, 沈降中のデンドライトが堆積層

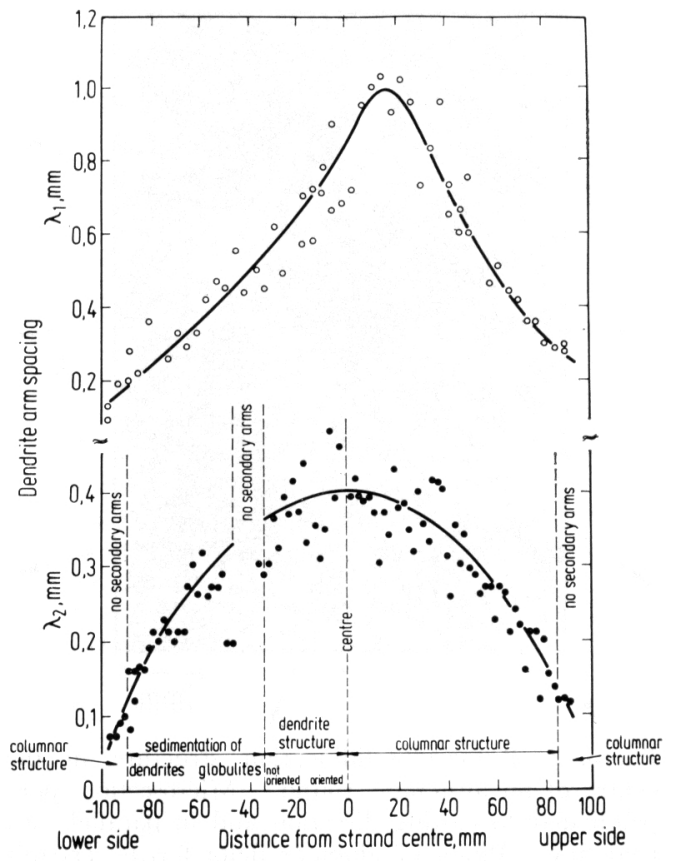

Fig. 7 Change of primary and secondary dendrite arm spacings in a strand slab cast at low temperature. 
の下面側境界で堆積することによつて始まり，上面側境 界に扎ける粒状晶の堆積をもつて終了する. 堆積層内の 粒状晶間隙で成長する二次アーム堆積層の上面側境界 付近には存在しない。これらのことから，堆積層内上部 の結晶は，成長粗大化するのに十分な時間の間残溶鋼に 取り囲まれていたと推察される.

柱状晶帯の発達が結晶の堆積によつて阻止され, 沈降 結晶クラスターの充填が粗になると, 結晶堆積層内に有 限の間隙が生じる ${ }^{18)}$. Photo. 3 は堆積層内の沈降結晶 間隙にデンドライトが成長しているよい例である，この 組織写真はオーステナイト系ステンレス鋼の丸形鋳片の 中心部分のものである. 同写真に和いて, 初晶として凝 固した $\delta$ 鉄が粒状晶の形で堆積したと考兄られるが，粒 状晶内に㴻結晶成長方向はランダムである。しか し，このランダムな成長方向にもかかわらず，婎積した 粒状晶間の間隙では凝固の進行に伴つて方向性のあるデ ンドライト成長が起こつている．Photo. 3 の組織を構 成する粒状晶と乞の間隙のデンドライトの成長方向は互 いに無関係であり，放射状の熱流の向きが間隙に拈ける デンドライトの成長方向を支配している。な执，难積層 内に和ける粒状晶の体積分率ないしは層の固相率が小さ

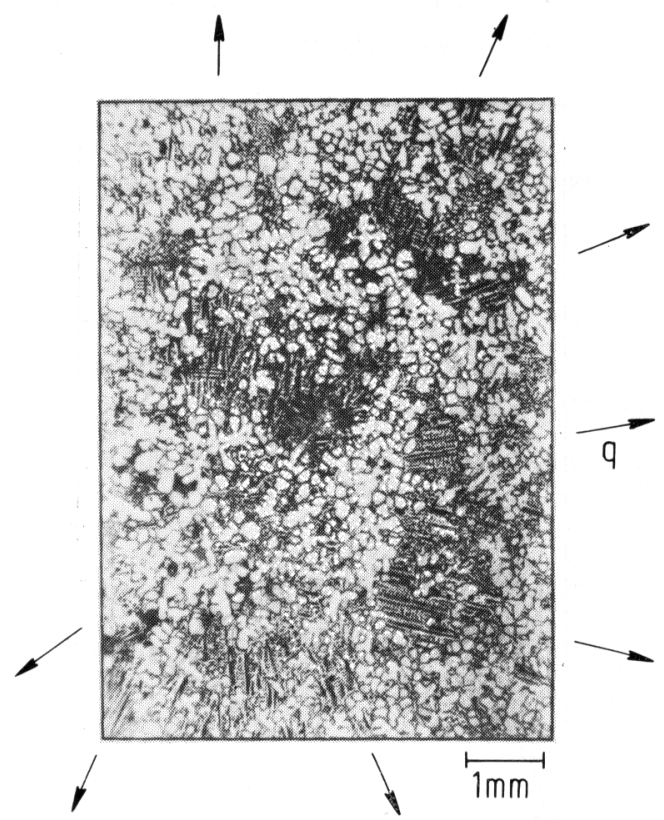

Photo. 3. Primary solidification structure in the centre of an austenitic round. Microsection perpendicular to casting direction and in parallel with heat flow. Piling of globular delta ferrite crystals and directional dendritic residual solidification in the voids. The arrows designate heat flow and direction of growth of the interglobular dendrites.
いため，粒状晶の界面は凝固期間中不安定であつたと思 われる ${ }^{23)}$. 粒状晶間隙で融体は报乞らく直接オーステナ イトとして凝固し, 融体に囲まれた $\delta$-粒状晶は $\delta$ - $\gamma$ 変 態の核生成抑制のために後になつて初めて $\gamma$ 相に変化し たものと考光られる。

\section{6. 溶質元素の分布}

鋳片内の溶質分布は凝固速度や残溶鋼の流動拈よび凝 固組織の 形成などに依存する3)5)10)11)17) 22)。本研究で は，典型的な鋳造組織を有するスラブ鋳片内の溶質分布 を，分光分析に基づき種々調査した。

高温鋳造で得られたスラブ鋳片の厚さ方向の炭素濃度 分布を, 参考のために Fig. 8 に示す. この条件下で は，凝固組織は鋳片断面全域にわたつて柱状晶である。 同図に㧊いて，炭素濃度峙鋳片表皮部より鋳片中心部直 前まで一定であるが，サクションによる残溶鋼の流動の ため中心部で濃度が減少している5) 11)24)25)。な拈, 中心 偏析の代表值を統計的に求めるには, 鋳片断面内に拈け る多数の分析点ときわめて小さな分析試料の採取が必要 となる。本研究では, 採用した分光分析によつて正偏析 の代表值を決めることが困難であつたため，Fig. 8 と 後述与る Fig. 9 と 10 の鋳片中心部にはこの正偏析值 をプロットせず空白のま残してある。

Photo. 2 に示されるように，鋳造温度を下げて遷移 温度で鋳造すると，鋳片中心部はまだ柱状晶凝固をして いるが，鋳片下面側に粒状等軸晶带が形成される。この 場合の濃度分布の実測值を Fig. 9 に示す. 同図より, 炭素濃度が 2 つ領域で減少していることがわかる.

さらに鋳造温度を下げると，粒状晶領域は鋳片中心ま で拡がる.この場合の炭素濃度分布の分析結果を Fig.

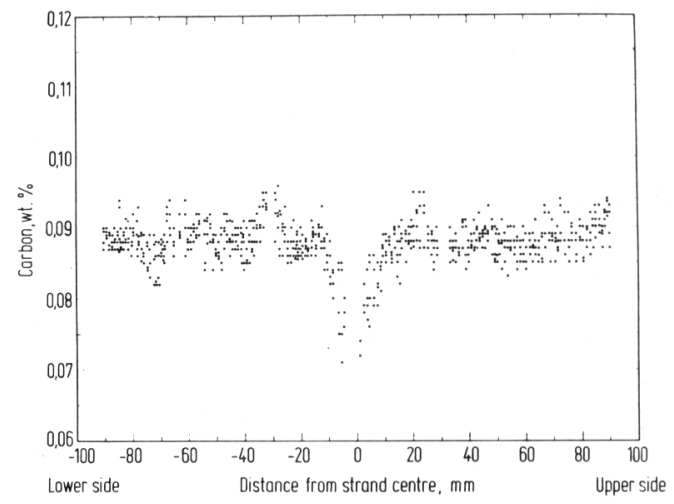

Fig. 8. Concentration profile of carbon in a strand slab of all-columnar solidification structure. (casting temperature $>$ "transition temperature") 


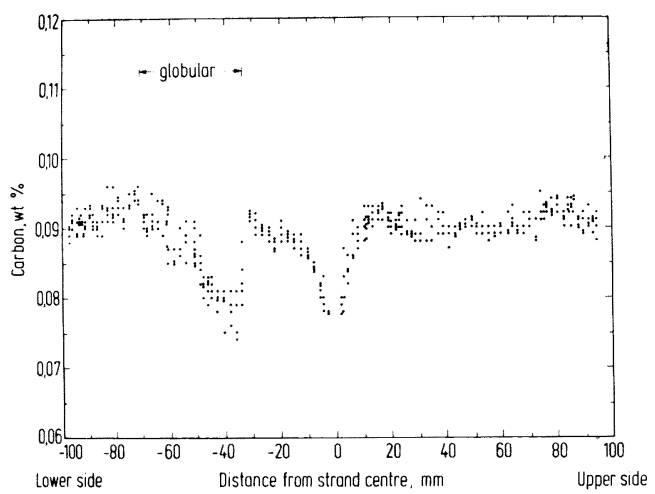

Fig. 9 Concentration profile of carbon in a strand slab of partly globular and partly columnar solidification structure. (casting temperature $=$ "transition temperature")

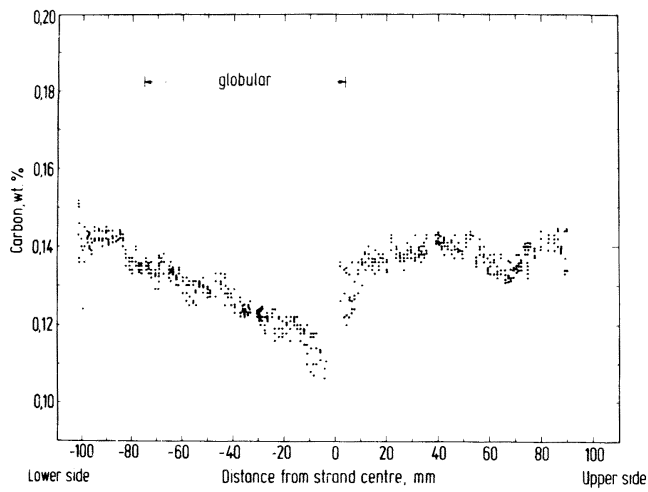

Fig. 10. Concentration profile of carbon in a strand slab of partly globular and partly columnar solidification structure. (casting temperature $<$ "transition temperature")

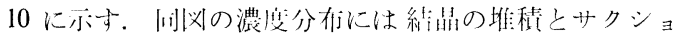

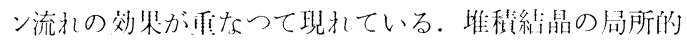

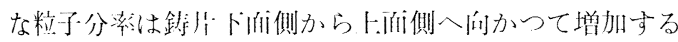

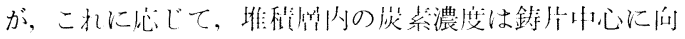

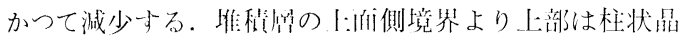
凝国領域であるため, この壋界で濃度が柋に增加するこ とになる. Fig. 9 と 10 の苂系濃度分布は粦状等軸晶

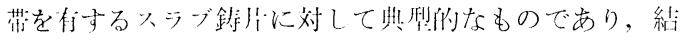
晶の沈降堆积機蓝の明ドな証拠であると考えられる26).

\section{7. 遷移現象としての結晶生成と沈降堆積}

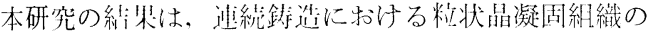
形成機棈のより詳しい船明に役立つものと考光られる.

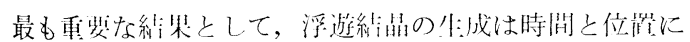

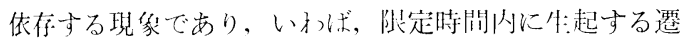

移現象であることがわかつた．絬晶牛成と沈降堆積は凝 阔殸が成烓し始める晹而から数 $\mathrm{m}$ の籁困内でしか起こら ないため，溶鋼過熱度の低減は粘状等軸晶带の桩大にと つて必装条件であるが十分条件ではない，すなわも，い つたん起こり始めた結;晶生:成と沈降堆積は鋳片の凝固完 了揓のある時期に終了し，この時期までしか浮遊絬晶の 生成が起こらない。したがつて, 結晶生成と沈降堆積は 定まつた时閏之位倠で終わるが，結晶が沈降し始める領 域は湯而から結晶珄成が終了する位喵までであり，溶鋼 過熱度に低存与る。浴鋼の過熱度が大きく，上述したよ らな溶鋼プールト蔀における浮遊結晶の生成を活用でき ない埸今には，電壣攪排のように，外部からの強力な溶 鋼攪汼によつて粘状唱又は等軸デンドライト細織を得る ことが可能である。

柱状晶凝润とか管軸品凝间にかかわらず，任意速度の 凝活は基本的には熱移動の䦌题之考元られる ${ }^{1872728)}$. 鋳

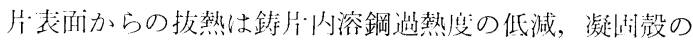
発達, 等軪唱凝湖を仵進し, 特に過熱度の低減は䊉状晶

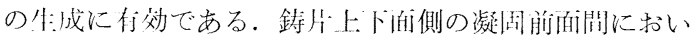

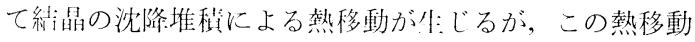

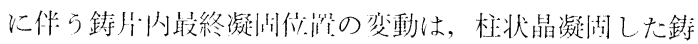
片の場合と比較すると, 特定冷期速修の条件ドでごくわ ずかしか梁められない。浮遊絬淐の発牛源である上面側

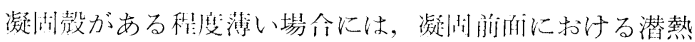

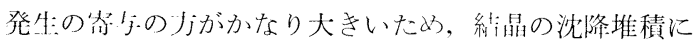
よる残溶鋼以部の熱移動が凝酎殸の発達に及ぼす效果は 極めて小さいと考えられる。

\section{文献}

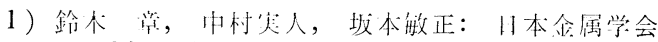
诘, 34 (1970), p. 802, p. 808

2) $T$. Kawawa: Preprints of The 2nd JapanGermany Seminar, (1976), p. 167 [ISIJ]

3 ) $T$. Nozaki, $T$. Mori, and $M$. Kawahara: Ironmaking Steelmaking, 4 (1977), p. 355

4 ) $P$. Stadler, $K$. Hagen, $P$. Hammerschmid, and $K$. Schwerdtfeger: Preprints of The 4th Japan-Germany Seminar, (1980), p. 201 [ISIJ]

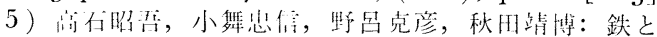
銅，60 (1974)，p. 915

6 ）根本秀太蚛：鉄之銅，60 (1974)，p. 755

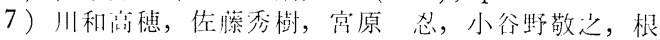
本秀太郎：鉄と鋼，60 (1974)，p. 486

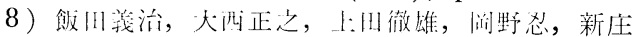
要：鉄と鋼，67 (1981), p. 1269

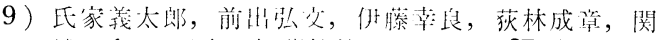

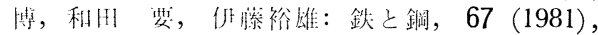
p. 1297

10）不坚守率，川1:公成，伊滕雅治，三好俊占：鉄と 銅， 60 (1974)， p. 885

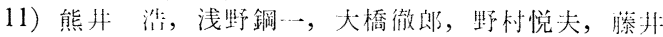
缚務：鉄と鋼，60 (1974)，p.894 
12) F. Weinberg: Solidification and Casting of Metals, (1979), p. 235 [The Metals Society, London]

13) $M . H$. Burden, $G . D$. Funnell, $A . G$. WhitaKER, and J. M. Young: 同上, p. 279 [The Metals Society, London]

14）川和高穂, 佐藤秀樹, 宮原 忍, 小谷野敬之, 根 本秀太郎：鉄と鋼，60 (1974)，p. 206

15）鈴木 章：鉄と鋼， 60 (1974), p. 774

16) T. Araki and K. GunjI: Preprints of The 2nd Japan-Germany Seminar, (1976), p. 91 [ISIJ]

17）佐々木寛太郎，杉谷泰夫，石村 進：鉄と鋼， 66 (1980), p. 43

18) $G$. Ebneth, $W$. Haumann, $K$. Rüttiger, and F. Oeters: Arch. Eisenhüttenw., 45 (1974), p. 353

19) $Y . K$. Chunang and $K$. Schwerdtfeger: Arch. Eisenhüttenw., 46 (1975), p. 303
20) E. Schürmann: Z. Metallk., 68 (1977), p. 602

21) $E$. Schürmann, $H$. Litterscheidt, and $K$. P. Mohr: Thyssen Techn. Bericht, 8 (1976), p. 15

22) $H$. Jacobi and $K$. Wünnenberg: Stahl u. Eisen, 97 (1977), p. 1075

23) T. Z. Katтamis: J. Crystal Growth, 18 (1973), p. 45

24) $K$. Schwerdtfeger: Stahl u. Eisen, 98 (1978), p. 225

25) $F$. Oeters and $M$. Seidler: Arch. Eisenhüttenw., 48 (1977), p. 481

26) $A$. Ohno and $T$. Motegri: $\Lambda$ FS Cast Metals Research J., (1975), p. 45

27) 大井 浩, 松野浮一：鉄と鋼，60 (1974), p.807

28) $K$. Miyazawa and $I$. Muchi: Trans. ISIJ, 15 (1975), p. 37 